\title{
Formononetin accelerates mycorrhization and increases maize production at low phosphorus application rates
}

\author{
JESSÉ V. DOS SANTOS, PAULA R.A. RIBEIRO, MARIA ANGÉLICA B. CARNEIRO, \\ ISAAC C. SOARES, IVAN V.A. FIORINI, LEANDRO L. CANCELLIER, ADRIANO D. \\ VEIGA, CARLOS JULIANO B. ALBUQUERQUE, RENZO G. VON PINHO \& FATIMA M.S. \\ MOREIRA
}

\begin{abstract}
The formononetin biostimulant may be an option for reducing P fertilization once it stimulates mycelial growth of arbuscular mycorrhizal fungi and increases plant ability to take up nutrients through the roots, especially phosphorus. The objective of this study was to evaluate the effect of formononetin associated with phosphorus fertilization in maize. Field experiments were conducted in a randomized block design with a $3 \times 4$ factorial arrangement $\left(0,50\right.$ or 70 , and $140 \mathrm{~kg} \mathrm{ha}^{-1} \mathrm{P}_{2} \mathrm{O}_{5}$; and formononetin application rates: $0,25,50$, and $100 \mathrm{~g} \mathrm{ha}^{-1}$ ), with four replications. Formononetin (100 $\mathrm{g} \mathrm{ha}^{-1}$ ) increased the mycorrhizal colonization rate up to $30 \%$ in maize in the first four weeks after emergence when no P fertilizer was applied, and to $17 \%$ when 50 or $70 \mathrm{~kg} \mathrm{ha}^{-1}$ of $\mathrm{P}_{2} \mathrm{O}_{5}$ were applied. The application of 50 and $100 \mathrm{~g} \mathrm{ha}^{-1}$ of formononetin significantly increased plant height, ear height, and grain yield (22\% - 76\%) when no P fertilizer was applied. The use of formononetin in the field stimulates mycorrhizal colonization, has a positive effect on maize yield, and reduces the need for $P$ fertilizer application in maize. However, this effect was evident only at low P soil contents.
\end{abstract}

Key words: arbuscular mycorrhiza, biostimulant, isoflavonoid, Zea mays.

\section{INTRODUCTION}

Arbuscular mycorrhizal fungi (AMF), belonging to the Glomeromycota phylum, are important components of soil microbiota, have a generalized presence in the soil, and contribute to the diversification and stability of natural ecosystems (Van der Heijden et al. 1998). These fungi colonize the roots of most known plant species, including those of agricultural interest, establishing a mutual symbiotic association called arbuscular mycorrhizas (AMs) (Schüßler et al. 2001). Prominent functions performed by the AMF may include reduction in the use of fertilizers, especially phosphorus (P) (Tawaraya et al. 2012, Cozzolino et al. 2013, Ribeiro et al. 2016), relief from the effects of diverse stresses (Siqueira et al. 1999, Rangel et al. 2013, Schneider et al. 2013, Zayed et al. 2013), and promotion of soil aggregation and stabilization of the aggregates (Rillig \& Mummey 2006, Graf \& Frei 2013). These studies have shown that mycorrhizal plants develop more rapidly, are much better nourished, and are more tolerant to water deficit and stresses caused by toxic factors and by diseases (Folli-Pereira et al. 2012, Cordeiro et al. 2015).

Over the past decades, AMFs have attracted the interest of researchers, who have been trying 
to exploit their practical potential, especially in tropical regions. Many soils in tropical regions have high $\mathrm{P}$ fixation capacity and, consequently, low P availability (Yamada \& Abdalla 2004, Cordeiro et al. 2015). The AMFs have a very clear role in regard to expanding the capacity to take up not only insoluble $\mathrm{P}$, but also other macroand micronutrients (Miyasaka \& Habte 2001, Govindarajulu et al. 2005). In spite of the proven benefits of AMFs, their widespread agricultural use is limited by the impossibility of producing infective propagules on a large scale. However, the flavonoid formononetin has emerged as one alternative to this limitation (Nair et al. 1991, Siqueira et al. 1991, Silva-Júnior \& Siqueira 1997, Davies et al. 2005, Novais \& Siqueira 2009, Cordeiro et al. 2015, Ribeiro et al. 2016, Santiago et al. 2017).

Formononetin stimulates sporulation, spore germination, and mycelial growth of AMF in the soil, which, associated with the plant root system, expands plant capacity to take up essential elements, especially P (Nair et al. 1991, Siqueira et al. 1991, Baptista \& Siqueira 1994, Silva-Júnior \& Siqueira, 1997, Davies et al. 2005, Novais \& Siqueira 2009, Salgado et al. 2017, Silva et al. 2017). Formononetin mainly stimulates germination of native spores and mycelial growth, and can thus move up the process of fungal colonization in roots. Consequently, establishment of symbiosis can occur earlier. Earlier colonization by AMF makes the root system more effective in providing water and nutrients to plants (Gavito \& Miller 1998, Grant et al. 2005, Bittman et al. 2006, Seguel et al. 2012). In addition, mycorrhizas can contribute to reducing disease, improving plant health, either because AMF compete with diverse root pathogens for the same sites of infection, or they induce defense genes in the plant (Vigo et al. 2000, Pozo et al. 2002 Pozo \& Azcón-Aguilar 2007, Sikes et al. 2009, Wehner et al. 2010, Gallou et al. 2011, Jung et al. 2012, Cameron et al. 2013). Therefore, plants with extensive presence of mycorrhizas have competitive advantages over those with little presence, already in the first stages of development.

In various countries, formononetin is already used in agriculture as a stimulant of mycorrhization; however, this product is not yet sold in most tropical countries, including Brazil. As a large portion of world grain production is concentrated in tropical regions and in soils with low $\mathrm{P}$ availability, the use of formononetin is an alternative to maximize the benefits of mycorrhizas in increasing uptake of this nutrient. In Brazil, the maize crop generates one of the largest demands for phosphorus fertilizers (IPNI 2018). As maize is a mycotrophic plant, evaluating the effect of formononetin associated with different application rates of phosphorus on this crop in a field experiment will provide useful information that may support its use on a wide scale in agriculture. Use of formononetin may optimize the use of $\mathrm{P}$, whether by reducing the need for application of phosphorus fertilizers or by better exploiting the $P$ retained in the soil.

Therefore, the aim of this study was to evaluate the effect of application of formononetin, associated with phosphorus fertilization, on the maize crop.

\section{MATERIALS AND METHODS}

Experimentswereconducted in the municipalities of Lavras (210 $13^{\prime} 27^{\prime \prime} \mathrm{S}, 44^{\circ} 58^{\prime} 19^{\prime \prime} \mathrm{W}$, and $927 \mathrm{~m}$ altitude), Ijaci (21 $12^{\prime} 18^{\prime \prime} \mathrm{S}, 44^{\circ} 58^{\prime} 49^{\prime \prime} \mathrm{W}$, and $957 \mathrm{~m}$ altitude), and Uberlândia (18 $50^{\circ} 24^{\prime \prime} \mathrm{S}$, $48^{\circ} 14^{\prime} 57^{\prime \prime}$ W, and $840 \mathrm{~m}$ altitude) in the state of Minas Gerais, Brazil, in the 2010/11 crop year. In Lavras and ljaci, the experiments were repeated in 2011/12, for a total of five experiments. Climate in the region of Lavras and Ijaci in the 
Köppen classification is mesothermal type with a dry winter (Cwb), mean annual temperature of $19.3^{\circ} \mathrm{C}$, and rainfall of $1,411 \mathrm{~mm}$. Climate in the Uberlândia region is type Aw, characterized as rainy tropical, megathermal, typical of savannas, with a dry winter. Mean annual temperature is $23.1^{\circ} \mathrm{C}$, and main annual rainfall is $1,550 \mathrm{~mm}$.

In Lavras, the two experiments were set up in a Latossolo Vermelho Distrófico [dystrophic Red Latosol (Oxisol)] with clayey texture. The soil chemical characteristics before setting up the experiment were $\mathrm{pH}\left(\mathrm{H}_{2} \mathrm{O}\right) 5.8,4.9 \mathrm{mg} \mathrm{dm}^{-3} \mathrm{P}$ (Mehlich-1), $125 \mathrm{mg} \mathrm{dm}^{-3} \mathrm{~K}, 4.6 \mathrm{cmol}_{\mathrm{c}} \mathrm{dm}^{-3} \mathrm{Ca}, 0.4$ $\mathrm{cmol}_{\mathrm{c}} \mathrm{dm}^{-3} \mathrm{Mg}, 0.0 \mathrm{cmol}_{c} \mathrm{dm}^{-3} \mathrm{Al}, 4.0 \mathrm{cmol}_{\mathrm{c}} \mathrm{dm}^{-3}$ $\mathrm{H}+\mathrm{Al}, 410 \mathrm{~g} \mathrm{~kg}^{-1}$ clay, $240 \mathrm{~g} \mathrm{~kg}^{-1}$ silt, and $350 \mathrm{~g} \mathrm{~kg}^{-1}$ sand. Maize had been planted in this area in the last 10 years.

In Ijaci, the soil of the area of the two experiments was classified as a Latossolo Vermelho-Amarelo Distrófico [dystrophic Red Yellow Latosol (Oxisol)] with clayey texture and the following chemical characteristics: $\mathrm{pH}\left(\mathrm{H}_{2} \mathrm{O}\right)$ 6.5, $10.3 \mathrm{mg} \mathrm{dm}^{-3} \mathrm{P}$ (Mehlich-1), $101 \mathrm{mg} \mathrm{dm}^{-3} \mathrm{~K}, 3.8$ $\mathrm{cmol}_{\mathrm{c}} \mathrm{dm}^{-3} \mathrm{Ca}, 1.5 \mathrm{cmol}_{\mathrm{c}} \mathrm{dm}^{-3} \mathrm{Mg}, 0.0 \mathrm{cmol}_{\mathrm{c}} \mathrm{dm}^{-3}$ Al, $2.3 \mathrm{cmol}_{\mathrm{c}} \mathrm{dm}^{-3} \mathrm{H}+\mathrm{Al}, 570 \mathrm{~g} \mathrm{~kg}^{-1}$ clay, $80 \mathrm{~g} \mathrm{~kg}^{-1}$ silt, and $350 \mathrm{~g} \mathrm{~kg}^{-1}$ sand. Up to 2009, this area was covered with pasture (Brachiaria spp.), and maize was grown from 2009 on.

In Uberlândia, the experiment was set up in a Latossolo Vermelho Distroférrico [Dystroferric Red Latosol (Oxisol)], with clayey texture and the following chemical characteristics: $\mathrm{pH}\left(\mathrm{H}_{2} \mathrm{O}\right) 5.8$, $1.2 \mathrm{mg} \mathrm{dm}^{-3} \mathrm{P}$ (Mehlich-1), $54.7 \mathrm{mg} \mathrm{dm}^{-3} \mathrm{~K}, 1.0 \mathrm{cmol}_{c}$ $\mathrm{dm}^{-3} \mathrm{Ca}, 0.4 \mathrm{cmol}_{\mathrm{c}} \mathrm{dm}^{-3} \mathrm{Mg}, 0.1 \mathrm{cmol}_{\mathrm{c}} \mathrm{dm}^{-3} \mathrm{Al}, 2.9$ $\mathrm{cmol}_{\mathrm{c}} \mathrm{dm}^{-3} \mathrm{H}+\mathrm{Al}, 490 \mathrm{~g} \mathrm{~kg}^{-1}$ clay, $370 \mathrm{~g} \mathrm{~kg}^{-1}$ silt, and $140 \mathrm{~g} \mathrm{~kg}^{-1}$ sand. The area of the experiment had a Brachiaria grass cover for approximately the previous 20 years.

Soil pH was determined in a soil/ $\mathrm{H}_{2} \mathrm{O}$ suspension (1:2.5 w/v). The available potassium and phosphorus contents were extracted with Mehlich-1 solution (Mehlich 1953). Then K was determined by flame photometry and $P$ by colorimetry. Exchangeable $\mathrm{Ca}, \mathrm{Mg}$, and $\mathrm{Al}$ were extracted with $1 \mathrm{~mol} \mathrm{l}^{-1} \mathrm{KCl}$ solution. Both $\mathrm{Ca}$ and $\mathrm{Mg}$ were measured by atomic absorption spectrophotometry, and Al by titration. Soil texture was determined by the hydrometer method, according to Bouyoucos (1951).

The experiments were set up in randomized blocks in a $3 \times 4$ factorial arrangement, consisting of 3 phosphorus application rates $\left(\mathrm{P}_{2} \mathrm{O}_{5}\right): 0,70$, and $140 \mathrm{~kg} \mathrm{ha}^{-1}$ in Lavras and Uberlândia and 0 , 50 , and $100 \mathrm{~kg} \mathrm{ha}^{-1}$ in ljaci; and 4 application rates of formononetin (potassium salt of 7-hydroxy, 4'-methoxyisoflavone - commercial product PHC-506): 0, 25, 50, and $100 \mathrm{~kg} \mathrm{ha}^{-1}$, in powder form. The experimental plot was composed of four crop rows of $6 \mathrm{~m}$ length spaced at $0.80 \mathrm{~m}$, with four replications (blocks). Planting occurred in December of the years 2010 and 2011, and harvest in April 2011 and 2012.

The $\mathrm{P}_{2} \mathrm{O}_{5}$ was applied in the form of Monoammonium phosphate (MAP), in the formulation 10-54-00 at planting, at which time $40 \mathrm{~kg} \mathrm{ha}^{-1}$ of $\mathrm{N}$ in the form of urea was also applied, being careful to deduct the $\mathrm{N}$ content in the MAP, and $80 \mathrm{~kg}$ of $\mathrm{K}_{2} \mathrm{O}$ in the form of $\mathrm{KCl}$. Broadcast fertilization was carried out after 30 days at the following rates: $135 \mathrm{~kg} \mathrm{ha}^{-1} \mathrm{~N}$ in the form of urea, $90 \mathrm{~kg} \mathrm{ha}^{-1} \mathrm{~K}_{2} \mathrm{O}$ in the form of $\mathrm{KCl}$, and $60 \mathrm{~kg} \mathrm{ha}^{-1} \mathrm{~S}$ in the form of Sulfurgran (90\% S). After furrows were opened with a planter, fertilization and sowing was performed manually, leaving 4.8 plants per meter, aiming to obtain a final plant population of 60 thousand plants per ha.

Formononetin was directly applied on the seeds - seeds were placed in sterile plastic bags with the formononetin; the mixture was homogenized so that the product completely covered the seeds; and then the seeds were sown manually. In Lavras and ljaci, the maize 
cultivar GNZ 2004 was used, and in Uberlândia, PIONEER ${ }^{\circledR}$ P3646H (Herculex ${ }^{\circledR}$ ).

The following evaluations were made: mycorrhizal colonization rate (MCR), plant height $(\mathrm{PH})$, ear height $(\mathrm{EH}), 100$-grain weight (100GW), leaf nutrient concentrations, and maize grain yield (YIELD).

For evaluation of MCR, in Lavras and Ijaci in the 2010/11 crop year, roots were collected at 4 and 6 weeks after plant emergence. In Uberlândia in 2010/11 and in Lavras and Ijaci in the experiments of $2011 / 12$, collections were made only in the sixth week after emergence. Fine roots from 8 plants per plot were collected and stored in sterile plastic bags. In the laboratory, the roots were washed and then cleared in 5\% $\mathrm{KOH}$ solution. After that, the roots were washed in running water and acidified for 3-5 minutes in $1 \% \mathrm{HCl}$. The roots were then stained with trypan blue in $0.05 \%$ lactoglycerol (water:glycerol:lactic acid, 1:1:1) (Phillips \& Hayman 1970). The MCR was quantified by the stained root grid line intersect method and observed in a stereoscopic microscope, according to Giovannetti \& Mosse (1980).

During phenological stage 4, characterized by emergence of the flower tassel, leaf samples were taken for evaluation of nutrient concentrations. For that purpose, leaves opposite to and below the ears of four plants per plot were collected. The leaves were dried in a forced air circulation oven at $65^{\circ} \mathrm{C}$, and after reaching constant mass, they were ground and then analyzed in regard to $\mathrm{P}, \mathrm{K}, \mathrm{Ca}, \mathrm{Mg}, \mathrm{S}$, $\mathrm{Cu}, \mathrm{Fe}, \mathrm{Mn}$, and $\mathrm{Zn}$ concentrations, according to the methodology described by Malavolta et al. (1997). N concentrations were determined by the Kjeldahl method (Sarruge \& Haag 1979).

Plant height and ear height were evaluated during phenological stage 6 ( 10 weeks after emergence). At the end of the maize cycle, the effects of the treatments on grain yield (corrected to $14 \%$ moisture) were evaluated.

The data were subjected to analyses of variance and Scott-Knott mean values tests using the SISVAR statistical program (Ferreira 2014). The data regarding percentage of mycorrhizal colonization were transformed by arcsine $(x / 100)^{0.5}$.

\section{RESULTS}

The climatic data for the locations where the studies were carried out show that the mean monthly temperature was from $20-25^{\circ} \mathrm{C}$, and rainfall in the period of full crop development was greater than $100 \mathrm{~mm}$. This indicates conditions adequate for the crop (Figure 1).

The formononetin and phosphorus significantly $(p<0.05)$ affected all the characteristics evaluated, except for 100-grain weight (Table I and II).

The MCR ranged from $54 \%$ to $80 \%$ and was significantly affected $(p<0.05)$ by the $\mathrm{P}$ application rates, except in Uberlândia (Table II and III). The highest MCR $(p<0.05)$ mainly occurred at low $P$ application rates $(0,50$, and $70 \mathrm{~kg} \mathrm{ha}^{-1}$ de $\mathrm{P}_{2} \mathrm{O}_{5}$ ); the values of these rates were $\sim 14 \%$ greater than those observed at the higher $\mathrm{P}$ application rates (100 and $140 \mathrm{~kg} \mathrm{ha}^{-1} \mathrm{P}_{2} \mathrm{O}_{5}$ ).

Formononetin increased $(p<0.05)$ the MCR by $\sim 30 \%$ in the first four weeks (2010/11-1) after maize germination in Lavras and in Ijaci when the application rate of $100 \mathrm{~g} \mathrm{ha}^{-1}$ of the product was used without application of $\mathrm{P}_{2} \mathrm{O}_{5}$. Formomonotin increased MCR by $\sim 17 \%$ in the presence of 50 and $70 \mathrm{~kg} \mathrm{ha}^{-1} \mathrm{P}_{2} \mathrm{O}_{5}$, compared to the treatment without application of formononetin (Table III). In the collections made six weeks after emergence, there was a significant effect $(p<0.05)$ of the formononetin only at the rate of 50 or $70 \mathrm{~kg} \mathrm{ha}^{-1}$ $\mathrm{P}_{2} \mathrm{O}_{5}$ in Lavras in the two years studied and in 
a

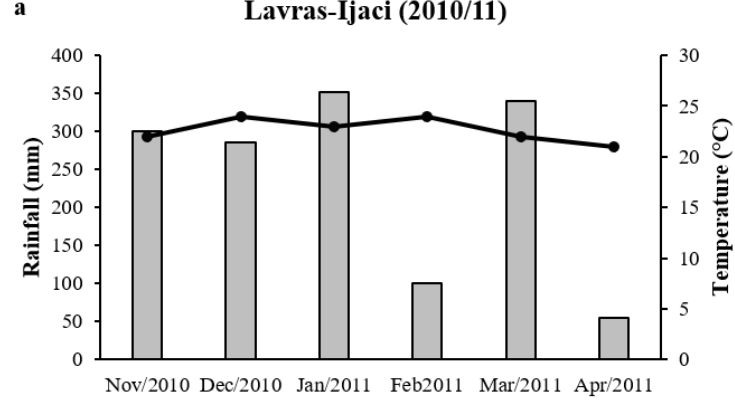

b

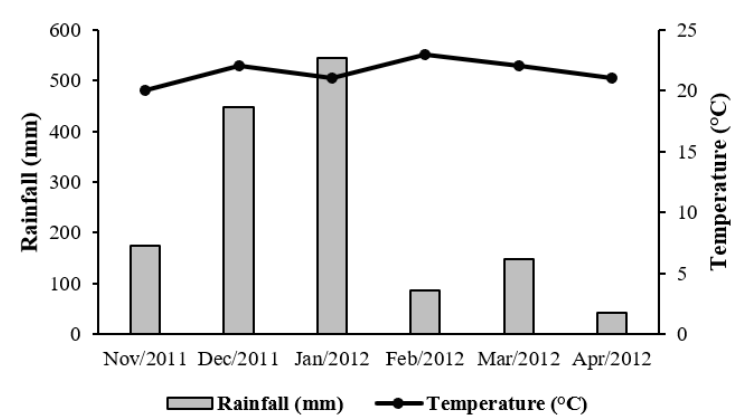

c

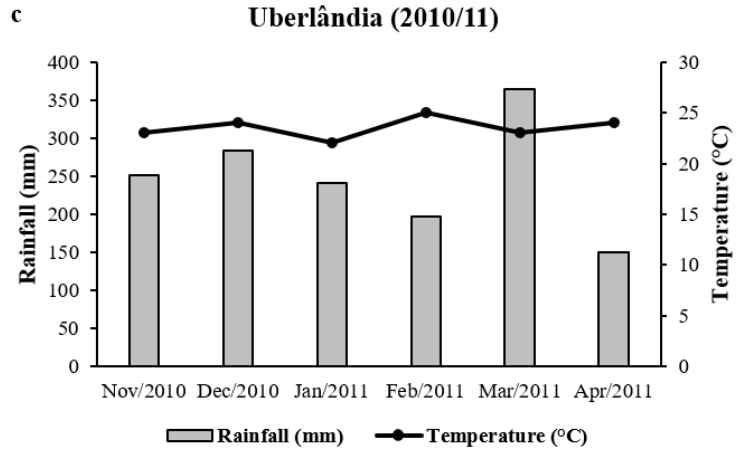

Figure 1. Rainfall and temperature in Lavras, ljaci, and Uberlândia in the period of conducting the experiments.

Ijaci in 2010 (Table III). Comparison of MCR in the (2010/11-1) and sixth (2010/11-2) week postemergence shows increases $(p<0.05)$ from $8 \%$ to $17 \%$ in this time interval.

Formononetin positively $(p<0.05)$ affected plant height in Lavras and ljaci in 2011/12 and ear height in Ijaci 2011/12 (Tables I and IV), but did not have a significant effect on 100GW (Tables I and V) nor on leaf nutrient concentrations (Table
SI - Supplementary Material). Regardless of the treatments, these factors were in the sufficiency ranges for crop development, as described by Malavolta et al. (1997) and Gott et al. (2014).

The mean maize grain yield was significantly $(p<0.05)$ affected by the $\mathrm{P}$ application rates in all the locations (Table VI). The highest maize yields occurred at application rates greater than $50 \mathrm{~kg}$ $\mathrm{ha}^{-1}$ of this element. When there was fertilization with $50 \mathrm{~kg} \mathrm{ha}^{-1}$ or more of $\mathrm{P}_{2} \mathrm{O}_{5}$, the yields were around $13 \%$ - 51\% higher than in the treatments without fertilization. At $P$ rates above $50 \mathrm{~kg}$ $\mathrm{ha}^{-1}$, effects $(p<0.05)$ were not observed from formononetin on maize yield. Nevertheless, in the absence of $P$ application, the use of 50 and $100 \mathrm{~g} \mathrm{ha}^{-1}$ formononetin increased maize grain yield from $22 \%-76 \%$ in all locations (Table VI). Under these conditions, yield was increased an average of around 3400 to $5600 \mathrm{~kg} \mathrm{ha}^{-1}$ in Lavras 2010/11, 4100 to $7100 \mathrm{~kg} \mathrm{ha}^{-1}$ in Lavras 2011/12, $\sim 4300$ to $5600 \mathrm{~kg} \mathrm{ha}^{-1}$ in Ijaci 2010/11, 6300 to $7300 \mathrm{~kg} \mathrm{ha}^{-1}$ in ljaci 2011/12, and 3900 to $5871 \mathrm{~kg}$ ha ${ }^{-1}$ in Uberlândia.

\section{DISCUSSION}

The lower MCR (Table III) at high rates of $\mathrm{P}$ occurred because, when plants are nutritionally provided for, especially with $\mathrm{P}$, they diminish stimulation for mycorrhizal colonization (Nogueira \& Cardoso 2007, Reis et al. 2008, Balota et al. 2012, Balzergue et al. 2013). In fact, in mycorrhizal symbiosis, host plants provide photoassimilates to the fungi, while they supply the plants with nutrients and water. However, when the soil has good fertility, the root system of the plants is able to take up nutrients and water adequately, dispensing with the need for the fungi. Thus, indirectly, the application of phosphorus tends to reduce establishment of AMs (Costa et al. 2005, Nogueira \& Cardoso 
Table I. Summary of individual analysis of variance for each location of maize cultivation for plant height (PH), ear height (EH), and grain yield.

\begin{tabular}{|c|c|c|c|c|c|c|}
\hline \multirow{2}{*}{ Characteristic } & \multirow{2}{*}{ Source of Variation } & \multicolumn{2}{|c|}{ Lavras } & \multicolumn{2}{|c|}{ ljaci } & \multirow{2}{*}{$\begin{array}{c}\text { Uberlândia } \\
\text { 2010/11 }\end{array}$} \\
\hline & & $2010 / 11$ & $2011 / 12$ & $2010 / 11$ & $2011 / 12$ & \\
\hline \multirow{4}{*}{ Plant height } & Phosphorus (P) & $\star *$ & $\star *$ & $* *$ & $* *$ & NA \\
\hline & PHC-506 & ns & * & ns & ** & \\
\hline & $\mathrm{P} \times \mathrm{PHC}-506$ & * & ** & ns & * & \\
\hline & CV & 10.15 & 6.92 & 6.45 & 4.93 & \\
\hline \multirow{4}{*}{ Ear height } & Phosphorus (P) & $* *$ & $* *$ & $* *$ & $\star *$ & NA \\
\hline & PHC-506 & ns & ns & ns & ** & \\
\hline & $\mathrm{P} \times \mathrm{PHC}-506$ & $\star *$ & $\star *$ & ns & ** & \\
\hline & $\mathrm{CV}$ & 8.28 & 10.40 & 8.75 & 6.91 & \\
\hline \multirow{4}{*}{$\begin{array}{c}\text { 100-grain weight } \\
(100 \mathrm{GW})\end{array}$} & Phosphorus (P) & ns & ns & ns & ns & ns \\
\hline & PHC-506 & ns & ns & ns & ns & ns \\
\hline & $\mathrm{P} \times \mathrm{PHC}-506$ & ns & ns & ns & ns & ns \\
\hline & $\mathrm{CV}$ & 8.28 & 10.40 & 8.75 & 6.91 & 8.36 \\
\hline \multirow{4}{*}{ Yield } & Phosphorus (P) & $* *$ & $\star *$ & $\star *$ & $* *$ & $\star \star$ \\
\hline & PHC-506 & $\star *$ & $* *$ & $* *$ & ns & ns \\
\hline & $P \times P H C-506$ & $\star *$ & $\star *$ & * & ns & * \\
\hline & $\mathrm{CV}$ & 13.02 & 12.01 & 13.43 & 13.85 & 20.54 \\
\hline
\end{tabular}

**, *, and ${ }^{\text {ns }}$ - significant at 1\%, 5\%, and not significant, respectively, by the Scott-Knott test; NA - parameter not evaluated. PHC506 - commercial product (potassium salt of 7-hydroxy, 4'-methoxyisoflavone).

2007, Balota et al. 2012, Balzergue et al. 2013). In contrast, low P concentrations tend to stimulate symbiosis, which is reflected in higher root colonization rates.

The higher MCR observed in the fourth week (Table III), at 0 and $70 \mathrm{~kg} \mathrm{ha}^{-1} \mathrm{P}_{2} \mathrm{O}_{5}$, when 50 and $100 \mathrm{~g} \mathrm{ha}^{-1}$ formononetin were applied, occurred because this isoflavonoid favors earlier germination of AMF propagules, moving up the establishment of symbiosis (Nair et al. 1991, Siqueira et al. 1991, Silva-Júnior \& Siqueira 1997, Davies et al. 2005, Novais \& Siqueira 2009), compared to the treatments without the use of formononetin.
The difference in MCR of plants with and without application of formononetin after six weeks came to decline over time (Table III). This occurred because the plants that were not stimulated by the formononetin progressively came to have their roots colonized by AMF, later achieving values near those exhibited by the plants treated with formononetin, which already had high MCR values ( $67 \%$ to $77 \%$ ) from the fourth week on. This difference in the time of occupation of the symbiosis sites may be one of the key points of the benefit of formononetin for maize plants. Thus, plants with greater root colonization in the first stages have greater 
capacity for utilization of the soil and greater uptake of nutrients and water compared to plants with lower MCR.

In our study, we observed increases in maize grain yield of $70 \%$ in Lavras, $25 \%$ in ljaci, and $52 \%$ in Uberlandia when more than $50 \mathrm{~g}$ $\mathrm{ha}^{-1}$ formononetin were applied in the absence of phosphorus fertilization (Table VI). In these treatments, the higher rates of mycorrhization were observed from the fourth week on, indicating that the formononetin stimulated mycorrhization. Nevertheless, the mean yield achieved under these conditions, although quite expressive, in most cases was below the yields achieved when the soil was fertilized with more than 50 or $70 \mathrm{~kg} \mathrm{ha-1} \mathrm{P}_{2} \mathrm{O}_{5}$. Ribeiro et al. (2016) observed that the application of formononetin at planting of soybean fertilized with half the recommended $\mathrm{P}$ application rate led to increases in grain yield equivalent to that of the plots that had received the full $P$ application rate, indicating that formononetin can reduce the need for $P$ fertilization. These results show that the effect of formononetin is related to the availability of phosphorus. Indeed, formononetin acts directly on the AMF propagules present in the soil, stimulating them during the process of root infection of the plants (Nair et al. 1991, Siqueira et al. 1991, Romero \& Siqueira 1996). However, the mycorrhization process is controlled by the plant, which limits colonization by the fungus when it is well supplied with phosphorus. Reduction in mycorrhizal colonization due to greater availability of $P$ is a well-known effect and is generally related to the nutritional state of the plants. It is understood that wellnourished plants would express mechanisms to reduce the development or activity of AMF in the roots, seeking to reduce the energy spent on maintaining the fungi (Smith \& Read 2008, Balota et al. 2011). Siqueira et al. (2002) reported that, in part, to successfully obtain isoflavonoid-based products, nutritional or environmental conditions must impose some degree of stress on the crop in question. Indeed, the formononetin flavonoid was isolated and identified in clover plants (Trifolium repens) stressed by phosphorus deficiency (Nair et al. 1991, Siqueira et al. 1991), and the use of this stimulant in the synthetic manner on different plant species has shown positive results, including yield (Ribeiro et al. 2016, Salgado et al. 2017, Santiago et al. 2017).

Although a direct correlation cannot be made between mycorrhizal colonization and maize grain yield, we cannot disregard possible indirect benefits from the arbuscular mycorrhizas for this crop, especially because in our study, we observed that the effect of the formononetin in the absence of $\mathrm{P}$ fertilization was consistent in the two years studied. In addition, the fact that formononetin does not promote an increase in grain yield as high as the increases obtained by the addition of large amounts of phosphorus fertilizers does not make its use infeasible. The costs of transportation and application of the fertilizers must be taken into consideration. Formononetin is a powder and it can be applied directly in planters together with seeds at the time of planting, dispensing additional operations. In addition, few grams (50-100 g) of formononetin are applied per hectare, whereas the use of phosphorus fertilizers comes to dozens or hundreds of kilograms, requiring larger operations and machines for application in large crop fields.

Another relevant aspect is that in Brazil and in other tropical countries, maize grain yield can vary a great deal from one region to another. In the case of Brazil, for example, whereas in the South, Southeast, and Central West regions mean yield is higher than $6,000 \mathrm{~kg} \mathrm{ha}^{-1}$, in the North and Northeast regions, mean yield is below $3,600 \mathrm{~kg} \mathrm{ha}^{-1}$, with some states with 
mean yield below $1,000 \mathrm{~kg} \mathrm{ha}^{-1}$ (IBGE 2017). These discrepancies are related to the technological level used in each region, including low use or the absence of fertilizer application. Our studies showed positive responses to the application of formononetin in the absence of phosphorus fertilizer application, which may be a feasible alternative for these regions with low yields.

Table II. Summary of analysis of variance for mycorrhizal colonization rate (MCR) in maize plants.

\begin{tabular}{|c|c|c|c|c|c|c|c|c|}
\hline \multirow{2}{*}{ Characteristic } & \multirow{2}{*}{$\begin{array}{l}\text { Source of } \\
\text { Variation }\end{array}$} & \multicolumn{3}{|c|}{ Lavras } & \multicolumn{3}{|c|}{ ljaci } & \multirow{2}{*}{$\begin{array}{l}\text { Uberlândia } \\
2010 / 11^{b}\end{array}$} \\
\hline & & $2010 / 11-1^{a}$ & $2010 / 11-2^{b}$ & $2011 / 12^{b}$ & $2010 / 11-1^{a}$ & $2010 / 11-2^{b}$ & $2011 / 12^{b}$ & \\
\hline \multirow{4}{*}{ MCR } & $\begin{array}{c}\text { Phosphorus } \\
\text { (P) }\end{array}$ & ** & ** & ** & ** & ** & ** & ns \\
\hline & PHC-506 & ** & ** & ** & ** & ** & ns & ns \\
\hline & P $\times$ PHC-506 & $\star *$ & ns & $* *$ & $* *$ & ns & ns & ns \\
\hline & CV & 5.25 & 6.25 & 3.96 & 5.27 & 6.85 & 5.06 & 4.39 \\
\hline
\end{tabular}

${ }^{\mathrm{a}}-4$ weeks after emergence, ${ }^{\mathrm{b}}-6$ weeks after emergence; ${ }^{* *},{ }^{*}$, and ${ }^{\mathrm{ns}}$ - significant at $1 \%, 5 \%$, and not significant, respectively, by the Scott-Knott test. PHC-506 - commercial product (potassium salt of 7-hydroxy, 4'-methoxyisoflavone).

Table III. Mycorrhizal colonization rate (MCR) in maize plants cultivated under different application rates of formononetin associated with three application rates of $\mathrm{P}_{2} \mathrm{O}_{5}$ in the state of Minas Gerais in crop years 2010/11 and 2011/12.

\begin{tabular}{|c|c|c|c|c|c|c|c|c|}
\hline \multirow{2}{*}{$\begin{array}{c}\text { Phosphorus } \\
\qquad \begin{array}{c}\left(P_{2} O_{5}\right) \\
\left(k g h a^{-1}\right)^{a}\end{array}\end{array}$} & \multirow{2}{*}{$\begin{array}{l}\text { PHC-506 } \\
\left(\mathrm{g} \mathrm{ha}^{-1}\right)\end{array}$} & \multicolumn{3}{|c|}{ Lavras } & \multicolumn{3}{|c|}{ ljaci } & \multirow{2}{*}{$\begin{array}{c}\text { Uberlândia } \\
\text { 2010/11 }\end{array}$} \\
\hline & & $2010 / 11-1^{b}$ & $2010 / 11-2^{c}$ & $2011^{c}$ & $2010 / 11-1^{b}$ & $2010 / 11-2^{c}$ & $2011^{c}$ & \\
\hline \multicolumn{9}{|c|}{ 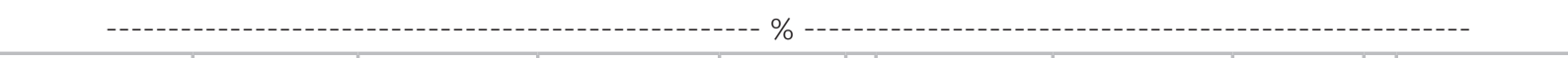 } \\
\hline \multirow{5}{*}{0} & 0 & $59.5 \mathrm{C}$ & $68.9 \mathrm{a}$ & $77.0 \mathrm{a}$ & $58.8 \mathrm{C}$ & $69.6 \mathrm{a}$ & $74.0 \mathrm{a}$ & $68.6 \mathrm{a}$ \\
\hline & 25 & $64.0 \mathrm{~b}$ & $72.7 \mathrm{a}$ & $79.1 \mathrm{a}$ & $61.8 \mathrm{C}$ & $74.9 \mathrm{a}$ & $76.9 \mathrm{a}$ & $69.1 \mathrm{a}$ \\
\hline & 50 & $68.1 \mathrm{~b}$ & $73.4 \mathrm{a}$ & $78.5 \mathrm{a}$ & $70.3 \mathrm{~b}$ & $76.4 \mathrm{a}$ & $77.5 \mathrm{a}$ & $66.9 \mathrm{a}$ \\
\hline & 100 & $76.9 \mathrm{a}$ & $77.3 \mathrm{a}$ & $80.5 \mathrm{a}$ & $76.2 \mathrm{a}$ & $77.8 \mathrm{a}$ & $79.3 \mathrm{a}$ & $71.7 \mathrm{a}$ \\
\hline & Mean & $67.1 \mathrm{~A}$ & $73.3 \mathrm{~A}$ & $78.8 \mathrm{~A}$ & $66.8 \mathrm{~A}$ & $74.6 \mathrm{~A}$ & $76.9 \mathrm{~A}$ & $69.1 \mathrm{~A}$ \\
\hline \multirow{5}{*}{70 or 50} & 0 & $64.5 \mathrm{~b}$ & $68.7 \mathrm{~b}$ & $64.4 \mathrm{~b}$ & $60.2 b$ & $68.6 \mathrm{~b}$ & $68.1 a$ & $66.2 \mathrm{a}$ \\
\hline & 25 & $63.0 \mathrm{~b}$ & $67.0 \mathrm{~b}$ & $64.8 \mathrm{~b}$ & $62.7 \mathrm{~b}$ & $68.8 \mathrm{~b}$ & $68.4 \mathrm{a}$ & $67.9 \mathrm{a}$ \\
\hline & 50 & $67.4 \mathrm{a}$ & $73.1 \mathrm{a}$ & $75.6 \mathrm{a}$ & $67.0 \mathrm{a}$ & $75.6 \mathrm{a}$ & $70.3 a$ & $71.0 \mathrm{a}$ \\
\hline & 100 & $71.6 \mathrm{a}$ & $75.8 \mathrm{a}$ & $79.1 \mathrm{a}$ & $71.6 \mathrm{a}$ & $76.2 \mathrm{a}$ & $72.6 a$ & $71.2 \mathrm{a}$ \\
\hline & Mean & $66.6 \mathrm{~A}$ & $71.1 \mathrm{~A}$ & $71.0 \mathrm{~B}$ & $65.4 \mathrm{~A}$ & $72.3 \mathrm{~A}$ & $70.0 \mathrm{~B}$ & $69.1 \mathrm{~A}$ \\
\hline \multirow{5}{*}{140 or 100} & 0 & $56.8 \mathrm{a}$ & $64.9 \mathrm{a}$ & $59.5 \mathrm{a}$ & $56.1 \mathrm{a}$ & $61.5 \mathrm{a}$ & $66.5 \mathrm{a}$ & $66.1 \mathrm{a}$ \\
\hline & 25 & $56.6 \mathrm{a}$ & $66.4 \mathrm{a}$ & $60.2 \mathrm{a}$ & $57.5 \mathrm{a}$ & $60.8 \mathrm{a}$ & $66.7 \mathrm{a}$ & $67.5 \mathrm{a}$ \\
\hline & 50 & $54.6 \mathrm{a}$ & $66.9 \mathrm{a}$ & $56.5 \mathrm{a}$ & $54.3 \mathrm{a}$ & $64.0 \mathrm{a}$ & $67.7 \mathrm{a}$ & $67.7 \mathrm{a}$ \\
\hline & 100 & $57.1 \mathrm{a}$ & $66.6 \mathrm{a}$ & $58.5 \mathrm{a}$ & $54.9 \mathrm{a}$ & $63.0 \mathrm{a}$ & $64.0 \mathrm{a}$ & $66.8 \mathrm{a}$ \\
\hline & Mean & $56.3 \mathrm{~B}$ & $66.2 \mathrm{~B}$ & $58.7 \mathrm{C}$ & 55.7 B & $62.3 \mathrm{~B}$ & $66.2 \mathrm{C}$ & $67.0 \mathrm{~A}$ \\
\hline
\end{tabular}

${ }^{\mathrm{a}} 70 \mathrm{~kg}$ ha-1 in Lavras and Uberlândia and 50 kg ha-1 in ljaci; ${ }^{\mathrm{H}} 4$ weeks after emergence; ' 6 weeks after emergence; lowercase letters compare MCR within formononetin; uppercase letters compare mean values of MCR in the phosphorus application rates by the Scott-Knott test at 5\% probability. PHC-506 - commercial product (potassium salt of 7-hydroxy, 4'-methoxyisoflavone). 
Table IV. Plant height and ear height of maize cultivated in the field under different application rates of formononetin associated with three application rates of $\mathrm{P}_{2} \mathrm{O}_{5}$ in the state of Minas Gerais in crop years 2010/11 and 2011/12.

\begin{tabular}{|c|c|c|c|c|c|c|c|c|c|}
\hline \multirow{2}{*}{$\begin{array}{c}\text { Phosphorus } \\
\qquad\left(P_{2} O_{5}\right) \\
\left(\mathrm{kg} \mathrm{ha}^{-1}\right)^{a}\end{array}$} & \multirow{2}{*}{ PHC-506 } & \multicolumn{4}{|c|}{ Lavras } & \multicolumn{4}{|c|}{ ljaci } \\
\hline & & \multicolumn{2}{|c|}{$2010 / 11$} & \multicolumn{2}{|c|}{$2011 / 12$} & \multicolumn{2}{|c|}{$2010 / 11$} & \multicolumn{2}{|c|}{$2011 / 12$} \\
\hline \multirow{5}{*}{0} & 0 & $1.80 \mathrm{a}$ & $1.52 \mathrm{c}$ & $0.86 a$ & $0.64 \mathrm{a}$ & $1.60 \mathrm{a}$ & $1.63 \mathrm{~b}$ & $0.85 \mathrm{a}$ & $0.88 \mathrm{~b}$ \\
\hline & 25 & $1.84 \mathrm{a}$ & $1.75 b$ & $0.93 a$ & $0.80 \mathrm{a}$ & $1.72 \mathrm{a}$ & $1.73 \mathrm{~b}$ & $0.90 \mathrm{a}$ & $0.91 \mathrm{~b}$ \\
\hline & 50 & $2.02 \mathrm{a}$ & $1.91 \mathrm{a}$ & $1.03 \mathrm{a}$ & $0.85 \mathrm{a}$ & $1.77 \mathrm{a}$ & $1.70 \mathrm{~b}$ & $0.96 \mathrm{a}$ & $0.93 \mathrm{~b}$ \\
\hline & 100 & $2.03 \mathrm{a}$ & $2.02 \mathrm{a}$ & $1.00 \mathrm{a}$ & $0.94 \mathrm{a}$ & $1.79 \mathrm{a}$ & $1.90 \mathrm{a}$ & $0.99 \mathrm{a}$ & $1.09 \mathrm{a}$ \\
\hline & Mean & $1.92 \mathrm{~B}$ & $1.80 \mathrm{C}$ & $0.96 \mathrm{~B}$ & $0.81 \mathrm{~B}$ & 1.72 B & $1.74 \mathrm{~B}$ & $0.92 \mathrm{~B}$ & $0.95 \mathrm{C}$ \\
\hline \multirow{5}{*}{70 or 50} & 0 & $2.24 \mathrm{a}$ & $2.10 \mathrm{a}$ & $1.19 a$ & $1.05 \mathrm{a}$ & $1.90 \mathrm{a}$ & $1.91 \mathrm{a}$ & $1.04 \mathrm{a}$ & $1.08 \mathrm{a}$ \\
\hline & 25 & $2.13 \mathrm{a}$ & $1.93 \mathrm{a}$ & $1.14 \mathrm{a}$ & $0.90 \mathrm{a}$ & $1.81 \mathrm{a}$ & $1.86 \mathrm{a}$ & $0.99 a$ & $1.03 \mathrm{a}$ \\
\hline & 50 & $2.25 \mathrm{a}$ & $2.14 \mathrm{a}$ & $1.23 \mathrm{a}$ & $1.01 \mathrm{a}$ & $1.84 \mathrm{a}$ & $1.92 \mathrm{a}$ & $1.00 \mathrm{a}$ & $1.12 \mathrm{a}$ \\
\hline & 100 & $2.21 \mathrm{a}$ & $2.02 \mathrm{a}$ & $1.14 \mathrm{a}$ & $0.99 a$ & $1.85 \mathrm{a}$ & $2.01 \mathrm{a}$ & $1.00 \mathrm{a}$ & $1.10 \mathrm{a}$ \\
\hline & Mean & $2.20 \mathrm{~A}$ & $2.05 \mathrm{~B}$ & $1.18 \mathrm{~A}$ & $0.99 \mathrm{~A}$ & $1.85 \mathrm{~A}$ & $1.93 \mathrm{~A}$ & $1.01 \mathrm{~A}$ & $1.08 \mathrm{~B}$ \\
\hline \multirow{5}{*}{140 or 100} & 0 & $2.09 \mathrm{~b}$ & $2.13 \mathrm{a}$ & $1.07 \mathrm{a}$ & $1.02 \mathrm{a}$ & $1.75 \mathrm{a}$ & $1.78 \mathrm{a}$ & $0.94 \mathrm{a}$ & $0.95 b$ \\
\hline & 25 & $2.55 \mathrm{a}$ & $2.22 \mathrm{a}$ & $1.22 \mathrm{a}$ & $1.13 \mathrm{a}$ & $1.88 \mathrm{a}$ & $1.97 \mathrm{a}$ & $1.05 \mathrm{a}$ & $1.11 \mathrm{a}$ \\
\hline & 50 & $1.98 \mathrm{~b}$ & $2.04 \mathrm{a}$ & $0.99 a$ & $0.98 \mathrm{a}$ & $1.76 \mathrm{a}$ & $1.79 b$ & $0.94 \mathrm{a}$ & $0.98 \mathrm{~b}$ \\
\hline & 100 & $2.23 \mathrm{a}$ & $2.22 \mathrm{a}$ & $1.17 \mathrm{a}$ & $1.07 \mathrm{a}$ & $1.87 \mathrm{a}$ & $1.92 \mathrm{a}$ & $1.04 \mathrm{a}$ & $1.06 \mathrm{a}$ \\
\hline & Mean & $2.21 \mathrm{~A}$ & $2.15 \mathrm{~A}$ & $1.11 \mathrm{~A}$ & $1.05 \mathrm{~A}$ & $1.82 \mathrm{~A}$ & $1.87 \mathrm{~A}$ & $0.99 \mathrm{~A}$ & $1.03 \mathrm{~A}$ \\
\hline
\end{tabular}

${ }^{\mathrm{a}} 70 \mathrm{~kg} \mathrm{ha}^{-1}$ in Lavras and Uberlândia and $50 \mathrm{~kg} \mathrm{ha}^{-1}$ in ljaci; lowercase letters compare plant and ear heights in formononetin application rates; uppercase letters compare in phosphorus application rates by the Scott-Knott test at $5 \%$ probability. PHC-506 - commercial product (potassium salt of 7-hydroxy, 4'-methoxyisoflavone).

\section{CONCLUSIONS}

At high phosphorus application rates (greater than $50 \mathrm{~kg} \mathrm{ha}^{-1}$ of $\mathrm{P}_{2} \mathrm{O}_{5}$ ), the rate of mycorrhizal colonization declined and the effects of formononetin were inhibited.

Formononetin did not have an effect on 100-grain weight and leaf nutrient concentrations in maize.
The application of formononetin at rates greater than $50 \mathrm{~g} \mathrm{ha}^{-1}$ increased the mycorrhizal colonization rate and the grain yield of maize grown in the field at low soil phosphorus contents. 
Table V. 100-grain weight (100GW) of maize, data obtained from plants cultivated under different application rates of formononetin associated with three application rates of $\mathrm{P}_{2} \mathrm{O}_{5}$ in the state of Minas Gerais in crop years 2010/11 and 2011/12.

\begin{tabular}{|c|c|c|c|c|c|c|}
\hline \multirow{2}{*}{$\begin{array}{c}\text { Phosphorus } \\
\qquad \begin{array}{c}\left(\mathrm{P}_{2} \mathrm{O}_{5}\right) \\
\left(\mathrm{kg} \mathrm{ha} \mathrm{h}^{-1}\right)^{\mathrm{a}}\end{array}\end{array}$} & \multirow{2}{*}{ PHC-506 } & \multicolumn{2}{|c|}{ Lavras } & \multicolumn{2}{|c|}{ ljaci } & \multirow{2}{*}{$\begin{array}{l}\text { Uberlândia } \\
\text { 2010/11 }\end{array}$} \\
\hline & & $2010 / 11$ & $2011 / 12$ & $2010 / 11$ & $2011 / 12$ & \\
\hline \multicolumn{7}{|c|}{ - } \\
\hline \multirow{5}{*}{0} & 0 & $27.8 \mathrm{a}$ & $29.1 \mathrm{a}$ & $28.8 \mathrm{a}$ & $29.2 \mathrm{a}$ & $17.7 \mathrm{a}$ \\
\hline & 25 & $28.9 a$ & $28.4 \mathrm{a}$ & $27.0 \mathrm{a}$ & $28.1 \mathrm{a}$ & $17.8 \mathrm{a}$ \\
\hline & 50 & $28.7 \mathrm{a}$ & $32.0 \mathrm{a}$ & $29.7 \mathrm{a}$ & $28.4 \mathrm{a}$ & $15.7 \mathrm{a}$ \\
\hline & 100 & $29.9 a$ & $30.2 \mathrm{a}$ & $29.0 \mathrm{a}$ & $28.4 \mathrm{a}$ & $17.0 \mathrm{a}$ \\
\hline & Mean & $28.9 \mathrm{~A}$ & $29.9 A$ & $28.6 \mathrm{~A}$ & $28.5 A$ & $17.1 \mathrm{~A}$ \\
\hline \multirow{5}{*}{70 or 50} & 0 & $29.5 a$ & $30.2 \mathrm{a}$ & $29.4 \mathrm{a}$ & $28.7 \mathrm{a}$ & $17.4 \mathrm{a}$ \\
\hline & 25 & $30.4 a$ & $30.5 \mathrm{a}$ & $29.0 \mathrm{a}$ & $29.1 \mathrm{a}$ & $17.9 \mathrm{a}$ \\
\hline & 50 & $29.0 a$ & $30.5 \mathrm{a}$ & $29.2 \mathrm{a}$ & $28.3 \mathrm{a}$ & $17.2 \mathrm{a}$ \\
\hline & 100 & $29.3 a$ & $29.4 \mathrm{a}$ & $29.1 \mathrm{a}$ & $29.5 \mathrm{a}$ & $17.7 \mathrm{a}$ \\
\hline & Mean & $29.4 \mathrm{~A}$ & $30.15 A$ & $29.2 B$ & $28.9 A$ & $17.6 \mathrm{~A}$ \\
\hline \multirow{5}{*}{140 or 100} & 0 & $29.9 a$ & $29.8 \mathrm{a}$ & $28.4 \mathrm{a}$ & $27.6 \mathrm{a}$ & $18.8 \mathrm{a}$ \\
\hline & 25 & $30.4 a$ & $31.0 \mathrm{a}$ & $29.4 \mathrm{a}$ & $28.2 \mathrm{a}$ & $18.3 \mathrm{a}$ \\
\hline & 50 & $29.6 a$ & $28.6 \mathrm{a}$ & $28.7 \mathrm{a}$ & $28.3 \mathrm{a}$ & $17.3 \mathrm{a}$ \\
\hline & 100 & $28.7 a$ & $29.5 \mathrm{a}$ & $29.1 \mathrm{a}$ & $28.5 \mathrm{a}$ & $17.6 \mathrm{a}$ \\
\hline & Mean & $29.6 \mathrm{~A}$ & $29.7 A$ & $29.3 \mathrm{~A}$ & $28.2 \mathrm{~A}$ & $18 \mathrm{~A}$ \\
\hline
\end{tabular}

${ }^{2} 70 \mathrm{~kg} \mathrm{ha}^{-1}$ in Lavras and Uberlândia and $50 \mathrm{~kg} \mathrm{ha}^{-1}$ in ljaci; lowercase letters compare mean values of 100-grain weight in formononetin application rates, and uppercase letters compare mean values in phosphorus application rates by the Scott-Knott test at 5\% probability. PHC-506 - commercial product (potassium salt of 7-hydroxy, 4'-methoxyisoflavone). 
Table VI. Maize grain yield in a field experiment under different application rates of formononetin associated with three application rates of $\mathrm{P}_{2} \mathrm{O}_{5}$ in the state of Minas Gerais in crop years 2010/11 and 2011/12.

\begin{tabular}{|c|c|c|c|c|c|c|}
\hline \multirow{2}{*}{$\begin{array}{l}\text { Phosphorus }\left(\mathrm{P}_{2} \mathrm{O}_{5}\right) \\
\left.(\mathrm{kg} \mathrm{ha})^{-1}\right)^{\mathrm{a}}\end{array}$} & \multirow{2}{*}{ PHC-506 } & \multicolumn{2}{|c|}{ Lavras } & \multicolumn{2}{|c|}{ ljaci } & \multirow{2}{*}{$\begin{array}{c}\text { Uberlândia } \\
\text { 2010/11 }\end{array}$} \\
\hline & & $2010 / 11$ & $2011 / 12$ & $2010 / 11$ & $2011 / 12$ & \\
\hline & --------- & ------ & $g h^{-1}---\cdot$ & ------ & --- & \\
\hline \multirow[t]{5}{*}{0} & 0 & $3472 b$ & $4160 c$ & $4272 b$ & $6322 b$ & $3918 b$ \\
\hline & 25 & $2869 b$ & $4554 C$ & $4443 b$ & $5567 b$ & $3778 b$ \\
\hline & 50 & $5853 a$ & $7699 a$ & $5493 a$ & $6954 a$ & $5283 a$ \\
\hline & 100 & $5354 a$ & $6573 b$ & $5647 a$ & $7590 a$ & $6462 a$ \\
\hline & Mean & $4387 C$ & $5747 \mathrm{~B}$ & 4964B & $6608 B$ & $4860 B$ \\
\hline \multirow[t]{5}{*}{70 or 50} & 0 & $7441 a$ & $7033 a$ & $5005 a$ & $7163 a$ & $6619 a$ \\
\hline & 25 & $7934 a$ & $6328 a$ & $5271 \mathrm{a}$ & $7468 \mathrm{a}$ & $5612 a$ \\
\hline & 50 & $7067 a$ & $6576 a$ & $5663 a$ & $7917 a$ & $5834 a$ \\
\hline & 100 & $7098 a$ & $6326 a$ & $5551 a$ & $6497 a$ & $6915 a$ \\
\hline & Mean & $7385 \mathrm{~A}$ & $6565 A$ & $5373 B$ & $7261 \mathrm{~A}$ & $6245 \mathrm{~A}$ \\
\hline \multirow[t]{5}{*}{140 or 100} & 0 & $5786 a$ & $6057 b$ & $5423 b$ & $7652 a$ & $8935 a$ \\
\hline & 25 & $6579 a$ & $6403 b$ & $6248 a$ & $7957 a$ & $8438 a$ \\
\hline & 50 & 4206b & 5996b & $5071 b$ & $7865 a$ & $9417 a$ \\
\hline & 100 & $6913 a$ & $7435 a$ & $6745 a$ & $7741 a$ & $7224 a$ \\
\hline & Mean & $5871 \mathrm{~B}$ & $6473 \mathrm{~A}$ & $5872 \mathrm{~A}$ & $7804 \mathrm{~A}$ & $8504 A$ \\
\hline
\end{tabular}

${ }^{a} 70 \mathrm{~kg} \mathrm{ha}^{-1}$ in Lavras and Uberlândia and $50 \mathrm{~kg} \mathrm{ha}^{-1}$ in ljaci; lowercase letters compare yields in formononetin application rates; uppercase letters compare mean yields in phosphorus application rates by the Scott-Knott test at $5 \%$ probability. PHC-506 commercial product (potassium salt of 7-hydroxy, 4'-methoxyisoflavone).

\section{Acknowledgments}

We thank the Conselho Nacional de Desenvolvimento Científico e Tecnológico (CNPq / Process 559120/20095) and the Ministério de Ciência e Tecnologia, for financial support and research productivity fellowships (FMS Moreira; RG VonPinho) and the Coordenação de Aperfeiçoamento de Pessoal de Nivel Superior (CAPES) for scholarships.

\section{REFERENCES}

BALOTA EL, MACHINESKI O \& SCHERER A. 2012. Mycorrhizal effectiveness on physic nut as influenced by phosphate fertilization levels. Rev Bras Cienc Solo 36: 23-32.
BALOTA EL, MACHINESKI O \& STENZEL NMC. 2011. Resposta da acerola à inoculação de fungos micorrízicos arbusculares em solo com diferentes níveis de fósforo. Bragantia 70: 166-175.

BALZERGUE C, CHABAUD M, BARKER DG, BÉCARD G \& ROCHANGE SF. 2013. High phosphate reduces host ability to develop arbuscular mycorrhizal symbiosis without affecting root calcium spiking responses to the fungus. Front Plant Sci 4: 1-15.

BAPTISTA MJ \& SIQUEIRA JO. 1994. Efeito de flavonóides na germinação de esporos e no crescimento assimbiótico do fungo micorrízico arbuscular Gigaspora gigantea. R Bras Fisiol Veg 6: 127-134.

BITTMAN S, KOWALENKO CG, HUNT DE, FORGE TA \& WU X. 2006. Starter phosphorus and broadcast nutrients on corn 
with contrasting colonization by mycorrhizae. Agron J 98: 394-401.

BouYoucos GJ. 1951. A recalibration of the hydrometer method for making analysis of soils. Agr J 43: 433-437.

CAMERON DD, NEAL AL, VAN WEES SCM \& TON J. 2013. Mycorrhiza-induced resistance: more than the sum of its parts? Trends Plant Sci 18: 539-545.

CORDEIRO MAS, FERREIRA DA, PAULINO HB, SOUZA CRFS, SIQUEIRA JO \& CARNEIRO MA. 2015. Mycorrization stimulant based in formononetin associated to fungicide and doses of phosphorus in soybean in the Cerrado. Biosci J 31: 1062-1070.

COSTA CMC, CAVALCANTE UMT, GOTO BT, SANTOS VF \& MAIA LC. 2005. Arbuscular mycorrhizal fungi and phosphorus supply on seedlings of mangabeira. Pesq Agropec Bras 40: 225-232.

COZZOLINO V, DI MEO V \& PICCOLO A. 2013. Impact of arbuscular mycorrhizal fungi applications on maize production and soil phosphorus availability. J Geochem Explor 129: 40-44.

DAVIES JR FT, CALDERÓN CM, HUAMAN Z \& GÓMEZ R. 2005. Influence of a flavonoid (formononetin) on mycorrhizal activity and potato crop productivity in the highlands of Peru. Sci Hortic 106: 318-329

FERREIRA DF. 2014. Sisvar: a Guide for its Bootstrap procedures in multiple comparisons. Ciênc Agrotec 38: 109-112.

FOLLI-PEREIRA MS, MEIRA-HADDAD LS, BAZZOLLI DMS \& KASUYA MCM. 2012. Micorriza arbuscular e a tolerância das plantas ao estresse. Rev Bras Cienc Solo 36: 1663-1679.

GALLOU A, MOSQUERA HPL, CRANENBROUCK S, SUÁREZ JP \& DECLERCK S. 2011. Mycorrhiza induced resistance in potato plantlets challenged by Phytophthora infestans. Physiol Mol Plant Pathol 76: 20-26.

GAVITO ME \& MILLER MH. 1998. Early phosphorus nutrition, mycorrhizae development, dry matter partitioning and yield of maize. Plant Soil 199: 177-186.

GIOVANNETTI M \& MOSSE B. 1980. An evaluation of techniques for measuring vesicular-arbuscular mycorrhizal infection in roots. New Phytol 84: 482-500.

GOTT RM, AQUINO LA, CARVALHO AMX, SANTOS LPD, NUNES PHMP \& COELHO BS. 2014. Diagnostic index for interpretation of foliar analysis of corn. Rev Bras Eng Agríc Ambient 18: 1110-1115.

GOVINDARAJULU M, PFEFFER PE, JIN H, ABUBAKER J, DOUDS DD, ALLEN JW, BÜCKING H, LAMMERS PJ \& SHACHAR-HILL Y.
2005. Nitrogen transfer in the arbuscular mycorrhizal symbiosis. Nature 435: 819-823.

GRAF F \& FREI M. 2013. Soil aggregate stability related to soil density, root length, and mycorrhiza using sitespecific Alnus incana and Melanogaster variegatus s.l. Ecol Eng 57: 314-323.

GRANT C, BITTMAN S, MONTREAL M, PLENCHETTE C \& MOREL C. 2005. Soil and fertilizer phosphorus: effects on plant $P$ supply and mycorrhizal development. Can J Plant Sci 85: 3-14.

IBGE - INSTITUTO BRASILEIRO DE GEOGRAFIA E ESTATÍSTICA. 2017. Indicadores IBGE. Levantamento Sistemático da Produção Agrícola Estatística da Produção Agrícola, Dezembro 2017. Acessado em 20 Set 2018. Disponivel em: https://biblioteca.ibge.gov.br/visualizacao/ periodicos/8/Ispa_prog_2017_dez_supl.pdf

IPNI - INTERNATIONAL PLANT NUTRITION INSTITUTE. 2018. Evolução do consumo aparente de N, P, K e Total de NPK no Brasil [internet]. Georgia, USA: International Plant Nutrition Institute Acessado em Jun 2018. Disponível em: http:// brasil.ipni.net/article/BRS-3132.

JUNG SC, MARTINEZ-MEDINA A, LOPEZ-RAEZ JA \& POZO MJ. 2012. Mycorrhiza-induced resistance and priming of plant defenses. J Chem Ecol 38: 651-664.

MALAVOLTA E, VITTI GC \& OLIVEIRA SA. 1997. Avaliação do estado nutricional das plantas: princípios e aplicações. Piracicaba: Potafos, 319 p.

MEHLICH A. 1953. Determination of P, Ca, Mg, K, Na and $\mathrm{NH}_{4}$. North Carolina Soil Testing Laboratories, Raleigh, NC. University of North Carolina, 8 p.

MIYASAKA SC \& HABTE M. 2001. Plant mechanisms and mycorrhizal symbioses to increase phosphorus uptake efficiency. Commun. Soil Sci Plant Anal 32: 1101-1147.

NAIR MG, SAFIR GN \& SIQUEIRA JO. 1991. Isolation and identification of vesicular-arbuscular mycorrhiza stimulatory compounds from clover (Trifolium repens) roots. Appl Environ Microb 57: 434-439.

NOGUEIRAMA \& CARDOSO EJBN. 2007. Phosphorus availability changes the internal and external endomycorrhizal colonization and affects symbiotic effectiveness. Sci Agric 64: 295-300.

NOVAIS CB \& SIQUEIRA JO. 2009. Aplicação de formononetina na colonização e esporulação de fungos micorrízicos em braquiária. Pesq Agropec Bras 44: 496-502.

PHILLIPS JM \& HAYMAN DS. 1970. Improved procedures for clearing roots and staining parasitic and vesicular 
arbuscular mycorrhizal fungi for rapid assessment of infection. Trans Br Mycol Soc 55: 158-161.

POZO MJ \& AZCÓN-AGUILAR C. 2007. Unraveling mycorrhizainduced resistance. Curr Opin Plant Biol 10: 393-398.

POZO MJ, CORDIER C, GAUDOT ED, GIANINAZZI S, BAREA JM \& AZCÓN-AGUILAR C. 2002. Localized versus systemic effect of arbuscular mycorrhizal fungi on defence responses to Phytophthora infection in tomato plants. J Exp Bot 53: 525-534.

RANGEL WM, SCHNEIDER J, COSTA ETS, SOARES CRFS, GUILHERME LRG \& MOREIRA FMS. 2013. Phytoprotective effect of arbuscular mycorrhizal fungi species against arsenic toxicity in tropical leguminous species. Int J Phytorem 16: 840-858.

REIS EF, CARNEIRO MAC, SAGGIN-JÚNIOR OJ, ROTTA DA \& SOUSA MY. 2008. Absorção de fósforo em doze genótipos de milho inoculados com fungo micorrízico arbuscular em solo de cerrado. Cienc Rural 38: 2441-2447.

RIBEIRO PRA, SANTOS JV, CARVALHO TS, REZENDE PM \& MOREIRA FMS. 2016. Formononetin associated with phosphorus influences soybean symbiosis with mycorrhizal fungi and Bradyrhizobium. Bioscience J 32: 940-951.

RILLIG MC \& MUMMEY DL. 2006. Mycorrhizas and soil structure. New Phytol 171: 41-53.

ROMERO AGF \& SIQUEIRA JO. 1996. Atividade de flavonóides sobre esporos do fungo micorrízico Gigaspora gigantea in vitro. Pesq Agropec Bras 31: 517-522.

SALGADO FHM, MOREIRA FMS, SIQUEIRA JO, BARBOSA RH, PAULINO HB \& CARNEIRO MAC. 2017. Arbuscular mycorrhizal fungi and colonization stimulant in cotton and maize. Cienc Rural 47: 1-8.

SANTIAGO FEM, NÓBREGA JCA, SANTIAGO FLA, EDVAN RL, NÓBREGA RSA \& MOREIRA FMS. 2017. Lime and phosphate application as mycorrhizae stimulation to enhance growth and yield of Marandu grass. Semina: Ciênc Agrár 38: 2323-2336.

SARRUGE JR \& HAAG HP. 1979. Análises químicas em plantas. Piracicaba: ESALQ, 27 p.

SCHNEIDER J, LABORY CRG, RANGEL WM, ALVES E \& GUILHERME LRG. 2013. Anatomy and ultrastructure alterations of Leucaena leucocephala (Lam.) inoculated with mycorrhizal fungi in response to arsenic-contaminated soil. J Hazard Mater 262: 1245-1258.

SCHÜßLER A, SCHWARZOTT D \& WALKER C. 2001. A new fungal phylum, the Glomeromycota: phylogeny and evolution. Mycol Res 102: 1413-1421.
SEGUEL A, MEDINA J, RUBIO R, CORNEJO P \& BORIE F. 2012. Effects of soil aluminum on early arbuscular mycorrhizal colonization of aluminum tolerant wheat and barley cultivars. Chil J Agric Res 72: 449-455.

SIKES BA, COTTENIE K \& KLIRONOMOS JN. 2009. Plant and fungal identity determines pathogen protection of plant roots by arbuscular mycorrhizas. J Ecol 97: 1274-1280.

SILVA JS, CARVALHO TS, SANTOS JV, RIBEIRO PRA \& MOREIRA FMS. 2017. Formononetin stimulates mycorrhizal fungi colonization on the surface of active root nodules in soybean. Symbiosis 71: 27-34.

SILVA-JÚNIOR JP \& SIQUEIRA JO. 1997. Aplicação de formononetina sintética ao solo como estimulante da formação de micorriza no milho e na soja. Rev Bras Fisiol Veg 9: 35-41.

SIQUEIRA JO, LAMBAIS MR \& STÜRMER SL. 2002. Fungos micorrízicos arbusculares: características, associação simbiótica e aplicação na agricultura. Biotec Cienc Desenv 25: 12-21.

SIQUEIRA JO, PEREIRA MAM, SIMÃO JBP \& MOREIRA FMS. 1999. Effect of formononetin (7 hydroxy 4'methoxy isoflavona) on mycorrhizal colonization and growth of corn in soil with excess of heavy metals. Rev Bras Cienc Solo 23: 571-577.

SIQUEIRA JO, SAFIR GR \& NAIR MG. 1991. Stimulation of vesicular-arbuscular mycorrhiza formation and growth of white clover by flavonoid compounds. New Phytol 118: 87-93.

SMITH SE \& READ DJ. 2008. Mycorrhizal Symbiosis. California: Academic Press, 800 p.

TAWARAYA K, HIROSE R \& WAGATSUMA T. 2012. Inoculation of arbuscular mycorrhizal fungi can substantially reduce phosphate fertilizer application to Allium fistulosum L. and achieve marketable yield under field condition. Biol Fertil Soils 48: 839-843.

VAN DER HEIJDEN MGA, KLIRONOMOS JN, URSIC M, MOUTOGLIS T, STREITWOLF-ENGEL R, BOLLER T, WIEMKEN A \& SANDERS IR. 1998. Mycorrhizal fungal diversity determines plant biodiversity, ecosystem variability and productivity. Nature 396: 69-72.

VIGO C, NORMAN JR \& HOOKER JE. 2000. Biocontrol of the pathogen Phytophthora parasitica by arbuscular mycorrhizal fungi is a consequence of effects on infection loci. Plant Pathol 49: 509-514.

WEHNER J, ANTUNES PM, POWELL JR, MAZUKATOW J \& RILLIG MC. 2010. Plant pathogen protection by arbuscular mycorrhizas: a role for fungal diversity? Pedobiologia 53: 197-201. 
YAMADA T \& ABDALLA SRS. 2004. Fósforo na Agricultura Brasileira, Piracicaba: Potafos. 726 p.

ZAYED MS, HASSANEIN MKK, ESA NH \& ABDALLAH MMF. 2013. Productivity of pepper crop (Capsicum annuum L.) as affected by organic fertilizer, soil solarization, and endomycorrhizae. Ann Agric Sci 58: 131-137.

\section{SUPPLEMENTARY MATERIAL}

\section{Table SI}

\section{How to cite}

SANTOS JV, RIBEIRO PRA, CARNEIRO MAB, SOARES IC, FIORINI IVA, CANCELLIER LL, VEIGA AD, ALBUQUERQUE CJB, VON PINHO RG \& MOREIRA FMS. 2020. Formononetin accelerates mycorrhization and increases maize production at low phosphorus application rates. An Acad Bras Cienc 92: e20181371. DOI 10.1590/0001-3765202020181371.

Manuscript received on December 20, 2018;

accepted for publication on April 2, 2019

\section{JESSÉ V. DOS SANTOS ${ }^{1}$}

https://orcid.org/0000-0003-4757-2658

PAULA R.A. RIBEIRO ${ }^{1}$

https://orcid.org/0000-0003-3620-3689

MARIA ANGÉLICA B. CARNEIRO²

https://orcid.org/0000-0001-8291-9333

ISAAC C. SOARES ${ }^{3}$

https://orcid.org/0000-0002-4189-5280

IVAN V.A. FIORINI ${ }^{4}$

https://orcid.org/0000-0002-1317-3475

\section{LEANDRO L. CANCELLIER ${ }^{4}$}

https://orcid.org/0000-0002-2565-2211

\section{ADRIANO D. VEIGA ${ }^{5}$}

https://orcid.org/0000-0003-2155-5198

\section{CARLOS JULIANO B. ALBUQUERQUE ${ }^{6,7}$}

https://orcid.org/0000-0003-2244-1336

\section{RENZO G. VON PINHO}

https://orcid.org/0000-0001-5276-2806

\section{FATIMA M.S. MOREIRA 3}

https://orcid.org/0000-0003-0159-5811
${ }^{1}$ Programa de Pós-Graduação em Microbiologia Agrícola, Universidade Federal de Lavras, Departamento de Biologia, Câmpus Universitário - Aquenta Sol, Caixa Postal 3037, 37200-900 Lavras, MG, Brazil

${ }^{2}$ Universidade Federal de Uberlândia, Instituto de Ciências Agrárias, Rua Acre, 1004, Umuarama, 38402-022 Uberlândia, MG, Brazil

${ }^{3}$ Universidade Federal de Lavras, Departamento de Ciência do Solo, Câmpus Universitário - Aquenta Sol, Caixa Postal 3037, 37200-900 Lavras, MG, Brazil

${ }^{4}$ Universidade Federal de Lavras, Departamento de Agricultura, Câmpus Universitário - Aquenta Sol, Caixa Postal 3037, 37200-900 Lavras, MG, Brazil

${ }^{5}$ Empresa Brasileira de Pesquisa Agropecuária - Embrapa Cerrados, BR-020, Km 18, Planaltina, 73310-970 Brasília, DF, Brazil

${ }^{6}$ Empresa de Pesquisa Agropecuária de Minas Gerais/ EPAMIG, Unidade Experimental do Triângulo e Alto Paranaíba, BR 050, Km 63, Zona Rural Via Araguari, Caixa Postal 2248, 38402-019 Uberlândia, MG, Brazil

${ }^{7}$ Universidade Federal de Minas Gerais, Instituto de Ciências Agrárias, Avenida Universitária, 1000, Universitário, 39404-547 Montes Claros, MG, Brazil

\section{Correspondence to: Fatima Maria de Souza Moreira}

E-mail:fmoreira@ufla.br

\section{Author contributions}

Jessé Valentim dos Santos contributed to the installation and conduct of experiments in the field, collection and processing of soil samples and plants, laboratory and data analysis, and scientific writing. Paula Rose de Almeida Ribeiro contributed to the installation of experiments in the field, collection of plants, laboratory analysis, and scientific writing. Maria Angélica Barcelos Carneiro, Isaac Carvalho Soares, Ivan Vilela Andrade Fiorini, Leandro Lopes Cancellier, Adriano Delly Veiga contributed to the installation and conduct of experiments in the field, collection plants, and scientific writing. Professor Carlos Juliano Brant Albuquerque and Renzo Garcia Von Pinho contributed to the project idealization, installation and conduct of experiments in the field data analysis, and scientific writing. and Professor Fatima Maria de Souza Moreira contributed to the project coordination and idealization, laboratory and data analysis, and scientific writing.

\section{(cc) BY}

